\title{
Assessing the Impact of a Number of Regional Securities Markets on Vietnam's Stock Market by Using Digital Statistical Technology
}

\author{
Pham Trung Nghia ${ }^{1,2}$
}

\author{
${ }^{1}$ People's Friendship University of Russia, Moscow, Russia \\ ${ }^{2}$ Tan Trao University, Tuyen Quang, Vietnam \\ Email:phamnghiatc@gmail.com
}

\begin{abstract}
In the context of globalization, more and more trade agreements between Vietnam and other countries have been signed. Vietnam's economy and finance are closely linked to the world's economy and finance. In order to evaluate the impact of the world stock market on the Vietnamese stock market, the author assessed the impact of some stock markets in the region on the Vietnam stock market. Specifically, Vietnam securities market is placed in relation with ASEAN and China stock markets.
\end{abstract}

Keywords: digital statistical technology, Vietnam's stock market, regional securities markets, ASEAN and China stock markets, economical relation

\section{INTRODUCTION}

The stock market has appeared in the world for centuries, but it was newly formed in Vietnam market more than 20 years ago. As a nascent stock market, Vietnam's stock market capitalization has increased nearly 17 times over the past 10 years (from $22.7 \%$ of GDP in 2006 to $78.5 \%$ of GDP by the end of the month. 6/2019), exceeding the government's target set by 2020 [1]. Vietnam's stock market currently has over 2.28 million investor accounts. The system of institutional investors is growing and expanding, the market has developed new types of funds, thereby promoting professionalism, efficient allocation of investment capital resources, creating sustainable demand and depth of market. However, as mentioned above, Vietnam's stock market is still very young, its size is small compared to other countries in the region and in the world. Therefore, regardless of changes, fluctuations of the global and regional stock markets have more or less impacted the Vietnam stock market. Therefore, researching and assessing the impact of the stock market in the region, we will have a basis, predict the majority of shareholders and have appropriate policies.

In addition, next-generation free trade agreements (FTA) such as the Comprehensive and Progressive Agreement for Trans-Pacific Partnership (CPTPP), FTA Vietnam European Union (EVFTA) or commitments in The framework of ASEAN common market integration ... has been promoting and requiring the financial market in general and Vietnam's stock market in particular to develop and open deeper and reach international standards. At the same time, this context also creates requirements forcing Vietnam's financial and stock markets to meet increasingly high quality standards in accordance with international commitments [1].

\section{BACKGROUND}

\subsection{History of Vietnam's stock market development}

Starting with the establishment of the State Securities Commission of Vietnam on November 28, 1996 under Decree No. 75/CP of the Government, 2 years later, the Vietnam stock market was officially born when the Decree the Government's Decree No. 48/CP was signed on July 11,1998 . On the same day, the Government also signed a decision to establish a Securities Trading Center and will base in Ho Chi Minh City and Hanoi. Less than 2 years later, on July 28, 2000, the Ho Chi Minh City Securities Trading Center (Ho Chi Minh Stock Exchange) officially came into operation, carrying out the first trading session with 2 stocks REE and SAM. Not long after that, the Hanoi Securities Trading Center (HNX) was officially launched on March 8, 2005. If Ho Chi Minh City Securities Trading Center is the place to list securities trading of large companies, the Hanoi Stock Exchange is the place where listing of small and medium enterprises [1].

Over the past 20 years, Vietnam's stock market has experienced a lot of fluctuations, but is also growing stronger, through many different stages.

From 2000-2005: considered as the start-up phase of the stock market, the market size is small with a market capitalization of less than 5\% of GDP. With a starting level of 100, VN-Index increased continuously after 12 months to reach a peak of 570 points on June 25, 2001. This period due to the fact that the goods were few at the beginning, the demand was much higher than the supply, 
leading to investors' competition to buy ceiling prices, causing the VN-Index to increase continuously. After reaching the peak of 570, VN-Index has adjusted down and down continuously for about 3.5 months, VN-Index lost $64 \%$ in value, to 203 points on October 5, 2001. Next is a rise of the index to 301 points before going into a twoyear decline period from November 2001 to November 2003. After that, the market went sideways in 2004 and 2005 [1].

Period from 2006-2007: Vietnam stock market entered the boom period. In early 2006, the VN-Index increased from the 300 point level to a peak of 1,174 on March 12, 2007 and the rest of the $2007 \mathrm{VN}$-Index fluctuated within the range of $900-1,100$ points. During this period, investors rushed capital into the market, scrambling to buy securities. The euphoria that led to uncontrolled push the Vietnamese stock market into an overheated growth, creating a "market bubble".

Period of 2008-2009: the stock bubble burst, stock indexes fell, the market prices of stocks fell sharply, and many stocks fell below par values. Poor liquidity market. Along with the impact from the world financial crisis originating from the US, VN-Index dropped further than many experts expected, returning to the starting line of the beginning of 2006 of 300 points. During this period, the management agencies issued many guidelines and supporting solutions, but did not prevent the decline of the stock market.

Period of 2010 to present: thanks to the improvement of macro economy and drastic restructuring of stock market, the stock market has certain growth steps. In the years 2010-2016, the market did not change much, the VNINDEX index fluctuated at 500-600 points. However, from 2017 , the stock market entered a period of growth again.

\subsection{Vietnam in the ASEAN stock market relationship}

The ASEAN Economic Community (AEC), one of the three pillars of ASEAN formed at the end of 2015, AEC is envisioned with the main characteristics: a unified market and production space; a highly competitive economic sector; an area of equal economic development; an economy fully integrated with the global economy [2-6]. A unified ASEAN market and production space encompasses five core elements: freedom of movement of goods; free flow of services; freedom of investment; more freedom in capital flow; freedom of skilled labor mobility Vietnam's stock market is characterized by a large number of listed companies but low average market capitalization, the current number of listed companies on both Ho Chi Minh City and Hanoi floors is 749 companies. Compared with other AEC countries, the number of listed companies in Vietnam is only lower than Malaysia, where there are 902 listed companies in 2018. The size of Vietnam's stock market is very small compared to other countries in the region. Currently, the market value of listed companies in Vietnam is about 147.1 billion USD, equivalent to $73 \%$ of GDP. While the total market capitalization of 7 ASEAN exchanges is approximately US $\$ 2,400$ billion with more than 3,000 listed companies in 6 countries [7-8]. In terms of market capitalization, Vietnam's stock market accounts for only $6.3 \%$ in ASEAN, less than $30 \%$ of the market value of Thailand, Indonesia, Singapore or Malaysia.

Especially, in 2018, compared with Singapore, the country with the largest market size, the Vietnamese market was only $1 / 5$ [9-11]. The institutional investor base on the Vietnamese stock market is very thin, most of the market participants are small investors so there may be a problem with the quality of the valuation. Concerns in the market to protect investors are the disclosure of reliable information, the transactions of related parties and the protection of customers' capital as well as financial security of securities brokers. Vietnam still has to try hard so that the stock market can catch up and integrate with the stock markets of ASEAN countries (Figure 1).

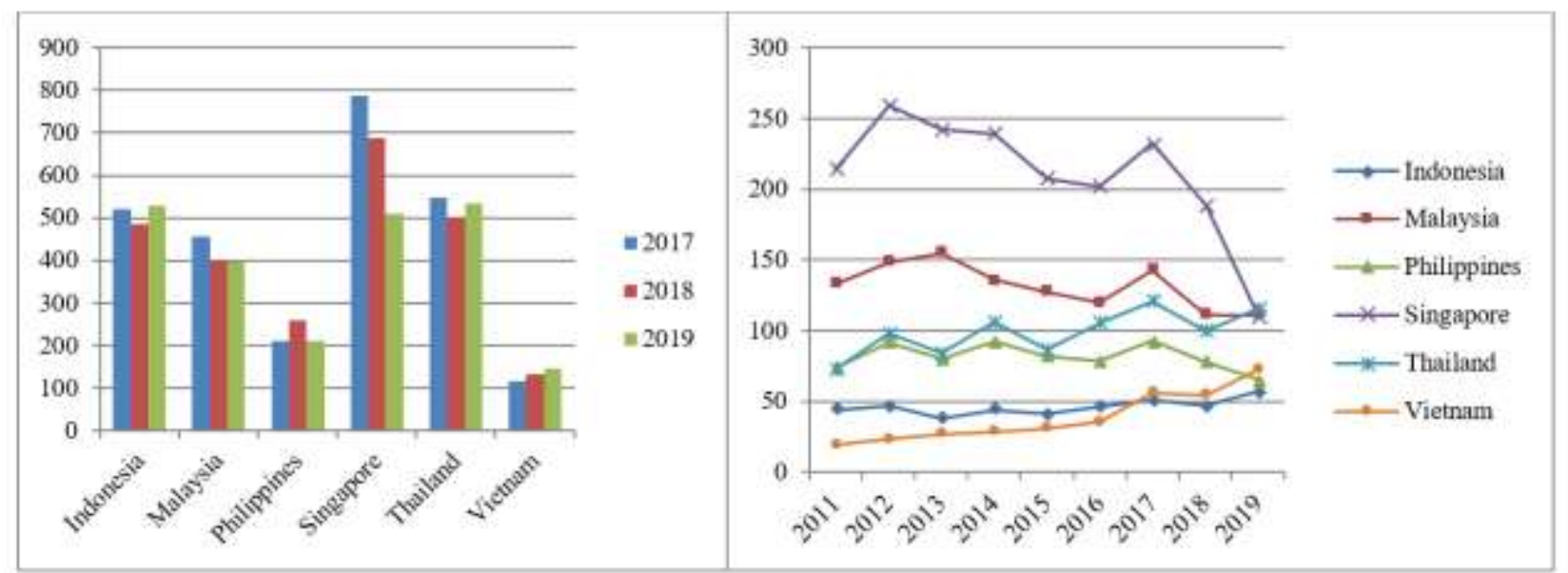

Figure 1 Market capitalization of listed companies (by billions USD and \%GDP).

Liquidity of the stock market is measured by the number of stock rotation during the year, showing that Vietnam's market liquidity has been unstable and low in recent years. On average during 2011 to 2019 , Vietnam market is better 
than Malaysia and Philippines market but inferior to Singapore, Indonesia and Thailand.

Vietnam Foreign Portfolio Investment is higher than the Philippines, Indonesia and Thailand as a whole. In particular, in 2013, while on a net basis, foreign investors withdrew capital from the stock markets of Singapore, Thailand and Indonesia, Vietnam still had a net capital inflow of approximately 1.6 billion USD (Figure 2).

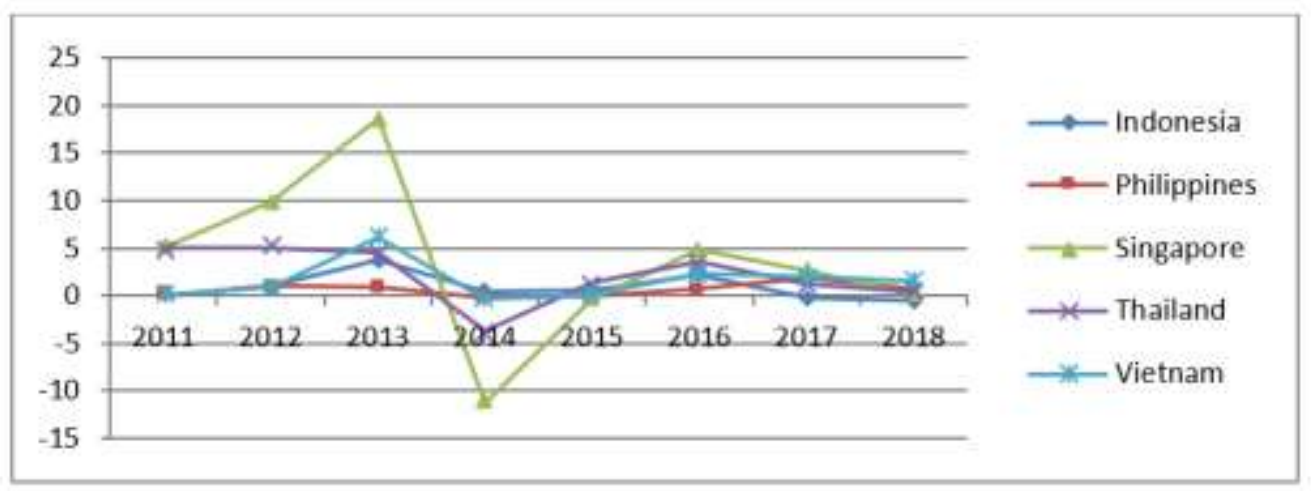

Figure 2 ASEAN Foreign Portfolio Investment (billion USD).

By implementing commitments in the financial sector when joining AEC, Vietnam's financial market will become connected with the markets of countries in the community, financial institutions and investors from other countries. Members may participate more deeply in Vietnam's insurance, banking and securities markets and vice versa. With the strength of the financial sector of Vietnam, in a comparison with ASEAN countries as above, financial integration will bring Vietnam many important benefits and many risks.

a. The benefits of integration

Firstly, liberalization of financial services promotes the development of the financial sector through improvements in products, services and technology transfer, thereby enhancing the competitiveness of financial institutions. Financial institutions have access to a wider customer base so they can take advantage of economies of scale, save costs, improve operational efficiency. Banks can raise more capital through the network operating throughout AEC and allocate this capital to more efficient investments. At the same time competition will also increase so customers will enjoy better services at more competitive prices, consumers will also have more financial products and services to choose from.

Secondly, capital market integration, investment liberalization and capital flows facilitate Vietnam to develop a more liquid, deeper and wider capital market. This helps to reduce capital costs, improve capital allocation and increase risk diversification in the market. Greater participation of foreign institutional investors in the stock market will contribute to the professionalization of Vietnam's stock market, enhance experience and improve the quality of analysis and investment valuation, and at the same time. Improve transaction and payment activities.

Thirdly, financial integration also imposes additional discipline on governments, banks, non-banking financial institutions and helps the economy to better withstand shocks. By harmonizing information disclosure standards, connecting regional securities markets will also make information disclosure, corporate governance, and investor protection of Vietnamese companies improved and closer to international standards.

$b$. The risks from integration

Firstly, domestic financial institutions must compete directly with stronger competitors from more developed countries than Vietnam in ASEAN region such as Singapore, Thailand, Malaysia, Indonesia and Philippines [12]. With the risk of losing customers or reducing relative market share. It is not excluded that the domestic financial services market is dominated by foreign organizations.

Secondly, liberalizing financial services and capital accounts can increase instability in the financial system and economy. According to ADB, increasing capital flows will boost credit growth, increase real exchange rate, create inflationary pressures, expand domestic demand and affect macro variables in a way that is not suitable for Current national policy goals. Increasing capital flows can also push up prices of stocks, real estate and other assets, causing asset bubbles as happened in Vietnam in 2006 and 2007 when foreign capital flows were massive flowed into Vietnam stock market after Vietnam joined the WTO. In addition, the freedom to conduct cross-border transactions may encourage foreign investors to pursue speculative activities, increasing the volatility of capital flows to Vietnam, especially the risk of sudden reversal of capital at large scale will cause financial market fluctuations thus causing instability to the economy.

\subsection{Vietnam in relation to the Chinese stock market}

According to statistics of the Chinese stock market, from the middle of June 2014 to the middle of June 2015, the Shanghai Composite Index (composite index of the 
marking the biggest drop since February 2007. Similarly, the Shenzhen Composite index also fell $7 \%$ on the same day. The Chinese stock market continued to witness a dark Tuesday (August 25, 2015) when the Shanghai Composite Index plunged $7.6 \%$ and the Shenzhen Composite index also fell $7.1 \%$, regardless of the intervention cards from banks, securities companies and large investment funds. Thus, in a very short time from June 12, 2015 to August 25, 2015, the Shanghai Composite Index decreased by $42.6 \%$, from $5,166,350$ points to $2,964,967$ points - a decrease. Unwanted record (Figure 3).

After a 3-week slowdown, Monday 27/7/2015 (Black Monday), the Shanghai Composite Index plunged $8.5 \%$,

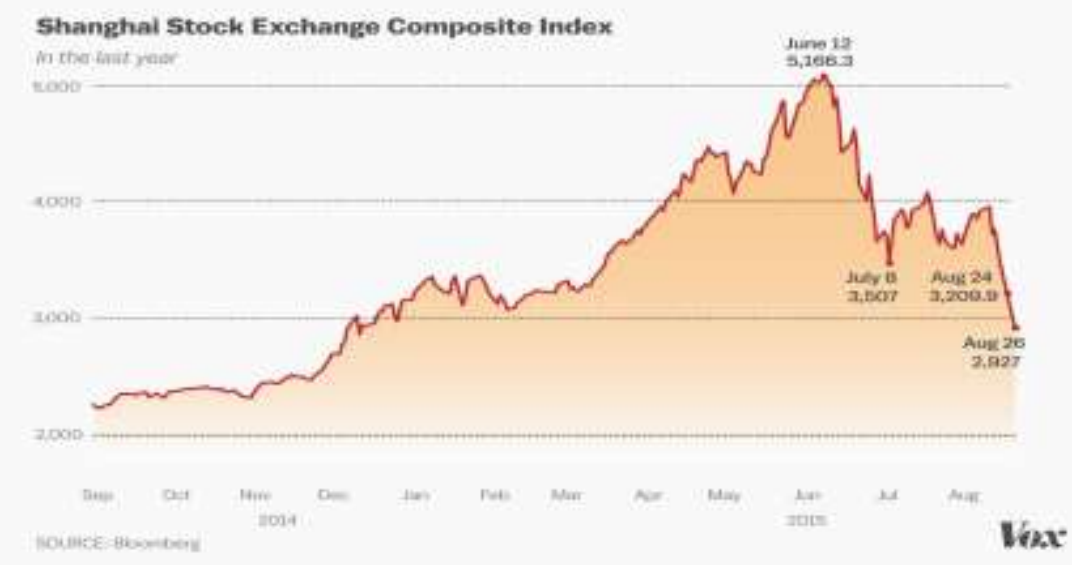

Figure 3 Volatility of Shanghai stock market September 2014 to August 2015 [14].

The collapse of China's stock market is due to the following main reasons: Growth of the stock market is not accompanied by economic growth: China's economy is in a prolonged downtrend. Economic growth slowed down with a gradual growth starting from 2010. GDP growth in 2014 was only $7 \%$. In order to stimulate a slowing economy, the government has continuously relaxed national monetary and monetary policies. Since the end of 2014, the People's Bank of China (PBOC) has continuously lowered interest rates and reduced reserve ratios. The key lending interest rate has decreased 3 times since $11 / 2014$ to $5.1 \%$; key interest rate dropped to $2.25 \%$. However, the amount of money borrowed back does not flow into the real economy. Instead of reinvesting, funds raised in the capital market return to the stock market (Figure 4).

Encourage buying stocks: China sees the stock market as the lifeblood of the economy. Beijing has instructed the state media to encourage securities investment, according to Lawrence W. Reed, president of the Foundation for Economic Education. In 2014, government spokesman Xinhua and the People's Daily published articles that encouraged people to invest in stocks. In an article published on August 31, 2014, Xinhua said that "economic and social development will bring valuable confidence and strong support in the stock market". About 40 million new accounts were opened between June 2014 and May 2015.

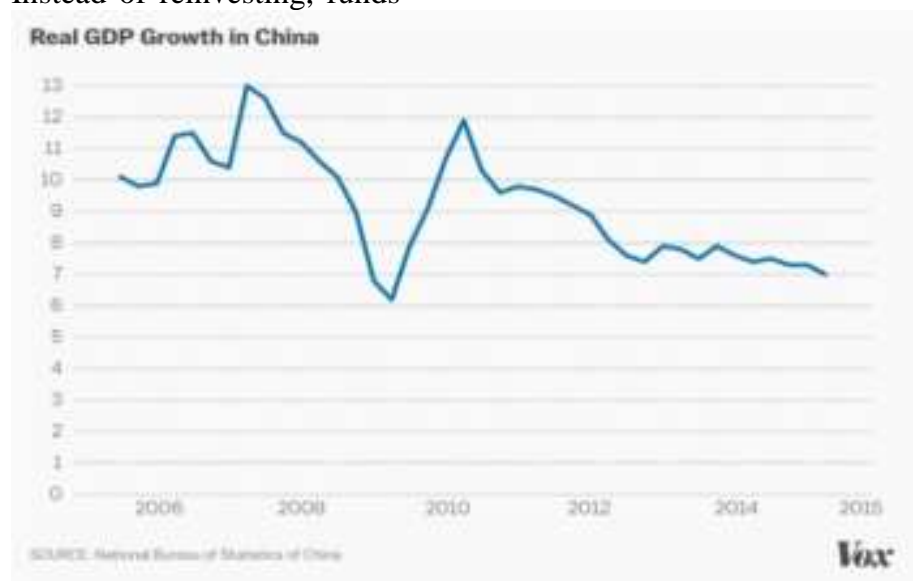

Figure 4 Actual GDP growth rate in China [14]. 
in English, building a centralized database system in proportion Foreign ownership...; develop and apply international standards and practices on information disclosure, corporate governance, risk management and investor protection, financial statements. Establish prudent management measures to protect the interests of domestic investors, the public as well as the domestic service market is still quite young under the pressure of competition from big countries. Removing obstacles / problems between securities laws and investment laws, laws on credit and banking related to foreign-invested activities.

\section{ACKNOWLEDGMENT}

This work was supported by Department of Environmental Police, People's Police Academy, Hanoi, Vietnam.

\section{REFERENCES}

[1] Cuong N, Bhatti M I and Darren Henry 2017 Physica A: Statistical Mechanics and its Applications 480 10-21.

[2] Azman-Saini W N M, Azali M, Habibullah M S and Matthews K G 2002 Applied Economics 34 2283-2288.

[3] Bekaert G and Harvey C 1997 Journal of Finance Economics 43 29-77.

[4] Brown R L, Durbin J and Evans JM 1975 Journal of the Royal Statistical Society 37 B 149-192.

[5] Chowdhury A $\mathrm{R} \quad 1994$ Journal of Macroeconomics 16 629-651.

[6] Daly K J 2003 ASEAN Economic Bulletin 20 (1) $75-85$.

[7] Dwyer G and Wallace M 1992 Journal of International Money and Finance 11 318-327.

[8] Hee N T 2002 Asian Economic Journal 16 (4) 353-377.

[9] Ibrahim M H 2019 Management Research News 28 (4) 93-115.

[10] Aggarwal S and Abhay R 2019 International Journal of Ethics and Systems 35 (1) 59-74.

[11] Muhammad A and Syed A S 2018 Journal of Risk and Financial Management 11(3) 32.

[12] Saifur R and Farihana S 2017 International Review of Applied Economics 31(1) 108-125. 
[13] Samiran J 2016 Global Business Review 17(5) 1240-1249.

[14] Chien M S, Lee C C, Hu T C and Hu H T 2015 Economic Modelling 51 84-98.

[15] Cheung Y L and Mak S C 1992 Applied Financial Economics 2 43-47. 